\title{
The Development of Ecological Concept of Village Residents in Honghe Prefecture after the Success of Application for World Heritage of Terraces
}

\author{
Min Liu \\ The College of Arts and Sciences \\ Yunnan Normal University \\ Kunming, China \\ Tianfu Yang \\ The College of Arts and Sciences \\ Yunnan Normal University \\ Kunming, China \\ Tan Jiang \\ The College of Arts and Sciences \\ Yunnan Normal University \\ Kunming, China
}

\author{
Yuwei Tao \\ The College of Arts and Sciences \\ Yunnan Normal University \\ Kunming, China \\ Min Zhang \\ The College of Arts and Sciences \\ Yunnan Normal University \\ Kunming, China \\ Laichun Niu \\ The College of Arts and Sciences \\ Yunnan Normal University \\ Kunming, China
}

\begin{abstract}
This article analyzes the change of Hani village residents' ecological concept after the success of application for world heritage of terraces via summarizing their "living with the nature" ecological concept based on site survey and with consideration of outside culture effect. This article takes the theory of sustainable development to consider how the Hani residents could enhance the ecological progress in the terrace area with their new ecological concept and tries to provide relevant development policies regarding mode of thinking, mode of economic development and "Beautiful Home Construction" etc.
\end{abstract}

Keywords-Hani terraces; ecological concept; sustainable development

\section{INTRODUCTION}

Hani terrace in Honghe village, as one world cultural landscape heritage, is located in Yuanyang County, Honghe Hani and Yi Autonomous Prefecture, southeastern part of Yunnan Province. It is a terraced farming civilization wonder created mainly by Hani people and other ethnic groups and a result of the special geographical climate of Ailao Mountain south of Red River, which is an immortal product of combination of culture and nature, a sculpture on Earth created harmoniously by man and nature. The total area of the Red River Hani Terraced Field is 461 square kilometers, of which the protected area is 166 square kilometers and the buffer area is 295 square kilometers. The terraced area is about 70 square kilometers or more than 10 million $m u$. The core scenic spots with concentrated terraces are: Bada, Duoyishu and Laohuzui, involving one town, two townships (Xi jie Town, Panzhihua
Township, Huang Mao Ling Township), 18 administrative villages, 82 natural villages and 11664 households, totally 56375 people $\%$

\section{II. "Living WiTh THE NATURE" ECOlOGICAL CONCEPT OF HANI PEOPLE}

Hani ethics people were originated from the ancient Qiang people group, after a long and hard migration, they settled in Ailao mountain area south of the Red River. During more than 1300 years living here, they were tolerant and courteous, in harmony with the rest of the world. The Hani terrace created by them distributed layer upon layer leaning the mountain and spread from foothill to the top of the mountain, which is more than 2000 meters long. The layers are over 3700, with a large scale, majestic and astounding. Hani terrace not only solved the water problem of rice cultivation, its forest conservation and terraced irrigation formed a vibrant ecosystem and farming culture, so it was still fundamental to Hani people material and spiritual life.

\section{A. Respect to Nature}

The Hani people take pride in the terrace. Terraced rice culture is the representative for productivity development of Hani nationality and the highest achievement of traditional agricultural production [1]. They are grateful to nature and God for grains of the nation, they give soul to primitive mountains in Ailao Mountain area, which is a benign interaction between man and nature and respect to nature. This rare and magnificent mind makes the Hani people in the Ailao 
Mountain work hard, improve themselves in their life. At the same time, it shapes national characters of the Hani people to be tenacious, optimistic and meditative.

\section{B. Intergrowth with Nature}

Hani's material life depends on the terraced fields, "to eat meat, climbing on the mountains, to farm, go to the foot of the mountain, to be born, stay at the mountainside" [2] This trinity of living space is the result of deep understanding and grasp to natural ecologic of Hani people in Ailao Mountain area. The spring in the forest flows into the terrace after using and layers of filtration, absorption in the terraces, finally gets into the river and turns into the water vapor to return to the forest, recycling water resources amazingly. The water samples collected from the terraces into the estuary show that water does not carry any pollutants after the absorption of the terraces. The forest is the "lifeblood" of the Hani people. They divide and protect the forests from the ecological sense, and form effective protective measures for the water forest, the god forest and the village forest, and appoint administrator to protect the forest. Based on the cyclical changes of the natural ecological environment of Ailao Mountain, the Hani people established a unique division of the seasonal occasion, phenology and the agricultural calendar that is more accurate and reasonable to meet the needs of the mountain terraces. The Hani family buildings' overall layout in the village embodies the nation's history and family spirit. The building materials coming from the crops in terrace and housing layout design fully show that they adapted to a greater humidity natural environment in the tropical mountains of Yunnan.

\section{Co-flourishing with Nature}

The Hani people who did not have the characters created "the name system of father and son ", "the name system of region's name", "the name system of master and apprentice ". This kind of social structure system gives the relationship between the Hani people, Hani family and Hani village certain kinship, and forms the stable benign social ecological structure of the Hani multi-storey and interpenetration [1] All the contents and forms of worship of the Hani primitive religion are almost all related to terraced farming worship and sacrifice ("Zaza suffer Festival", "Angma Festival" are two major festivals in the terraced farming), and rarely influenced by extrinsic religious beliefs. Hani people worship a lot of natural things, for example, the worship of the Heaven, the Earth, the water and the fire, the worship of the fertility of animals and the ability of plants to adapt to the natural environment, showing deep awesome of the Hani people to the natural existence. It is an important reason for the Hani terraced rice culture to exist in the Ailao Mountain area for nearly a thousand years. Hani's use of nature assures and promotes the optimal combination of natural ecosystems, agro-ecosystems and social ecosystems, reflecting the national trait of man and nature symbiosis.

In short, after thousands of years of evolution, Hani's terraced rice farming and lifestyle extend the life value of human and natural integration, embodying in tangible folk activities such as the Hani's basic necessities, weddings and funerals, festivals, religious sacrifices and intangible ideology such as the way of thinking, life attitude, principles of doing things, ethics and aesthetic intentions.

\section{THE DEVELOPMENT AND CHANGE OF THE ECOLOGICAL VIEW OF THE HANI TERRACED VILLAGE RESIDENCE BY THE FOREIGN CIVILIZATION}

The success of application for World Heritage of Hani terrace expands the influence of Hani culture in the world. However, this is a double-edged sword. It makes people all over the world see the Yuanyang terraces in China's Yunnan border and opens a window for Hani people to see the world. Under the influence of foreign civilization, the local residents' ecological consciousness is quietly changing.

When a large number of visitors see the magnificent terraces, marveling at "four elements is isomorphic" ecological layout in Hani area, Hani people profoundly realize their advanced ecological awareness and truly appreciate how valuable the Hani traditional way of planting and product growing are in today's materialistic society. "Terrace impression"(including red rice and blood rice) is a national rice brand growing and developing under the guidance of the government. They organize technical personnel to teach new technologies and encourage the villagers to plant, which is the real organic and green food, and Hani terraced areas are as a global organic food demonstration model base. The locals also recognize their own traditional products and the production mode are exactly what people living in city longing for. Only to further retain and develop their own traditional things, can they be able to bring themselves to a greater place, make Hani economy develop better, acquire the Hani people with wealth and make more people know Yuanyang terraced fields.

Hani's handicrafts are a manifestation and symbol of Hani culture, and many Hani women's handicrafts are popular with tourists, making Hani people more keen on learning and producing traditional handicrafts, and furthering inherit and promoting the Hani non-material cultural heritage as well.

With the opening of view, the Hani people realized the importance of education. With the increasing investment on education of government, the local people gradually experienced that "knowledge is the ladder of human progress", and that only to improve their knowledge, quality can be synchronized with the world, Hani culture can be inherited and continued.

At the same time, some inappropriate tourism development, affects every element that composed the "four elements" in the Hani terraces. A considerable number of young people in the terraced villages perennially work outside the village. Due to this, a lot of terraced trenches and ditches can't be repaired timely and a large number of ditches are blocked with poor water flowing, which affect the terraced farming. Affected by the negative impact of the market economy, the local villagers began to look for product of higher economic value and more relaxing way of planting. In the Hani terraced buffer zone, some paddy fields turned into dry farmland, on which planted bananas and other cash crops. Some villages even cut down the original miscellaneous trees to plant pure fir trees of higher economic value, reducing the capacity of forest water conservation[3][4]. 
In fact, Hani terraces themselves do not attract tourist, it has a self-circulation and digestive system. The current primary problem is how to maintain the original ecological, agricultural farming system and the natural environment in order to maintain the ecological balance and blend foreign civilization and traditional civilization.

\section{REMOLDING THE ECOLOGICAL VIEW OF HANI TERRACED VILLAGE RESIDENCES}

Any country who wants to enhance comprehensive national strength, he cannot avoid coordination and integration of science and technology, economy, resources, ecological environment and society.

Sustainable development theory has been recognized by the world. It refers to both meeting the current needs without weakening the needs of future generations and maintenance and rational use as well as improving the natural resource base. This foundation resists to ecological stress and economic growth, that is to say the development planning and policy should include concerns and considerations on environment, rather than a new kind of additional conditions.

In the 18th National Congress, the government highlights ecological civilization construction. It constitutes the "Five-inone" overall pattern of socialism with Chinese characteristics together with the economic construction, political construction, cultural construction and social construction.[5]. The 18th report clearly states that we must establish an ecological civilization concept of respecting nature, conforming to nature and protecting nature, and strive to build beautiful China and realize the Chinese natural dream.

We believe that we should cultivate ecological thinking. We must consider nurturing object first, focusing on the government's leading cadres; followed by the entrepreneur with economic strength; finally staff engaged in full-time environmental protection, law enforcement officers and local residents, and ultimately achieve the purpose of mass education. Their behaviors will have a significant impact on the ecological environment of the area.

In particular, we should establish the concept of "lifelong cultivation" in time. A person is in the training of "ecological thinking" from birth to death, which is fully reflected in Hani's natural ecological concept. It is a kind of "unity" consciousness between human beings and the ecological environment. It is an ecological wisdom, which embodies the ecological value of the Hani. However, more and more modern civilizations affect that of Hani ethic, especially the great changes of Hani younger generation on nature and material life. In order to cope with this change, we need to increase ecological and environmental education in the local school education, set up the corresponding environmental education center to carry out long-term publicity and education to the local residents.

Then, we should form a "big education" concept in space. We should break boundaries between school and training center, conduct propaganda education in the core area through the social culture environment and life practice and so on to make sure that everybody can accept the education on protecting Hani terraces.

\section{PROMOTING THINKING ON THE ECOLOGICAL}

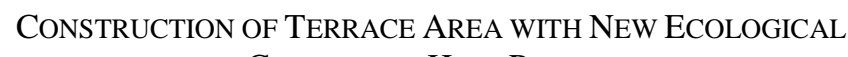
CONCEPT OF HANI PEOPLE

\section{A. Promoting the Ecological Way of Thinking}

Improving laws and regulations related to Hani terraced fields with the ecological way of thinking [6]. Further improving and implementing established relevant terrestrial protection laws and regulations. We should establish the corresponding laws on waste disposal, including relevant laws and regulations related to life waste, production waste and packaging and ensuring that the laws are implemented in the protection of the terraces. Implementing the "polluter burden" principle, we should change the past "who pollutes, who control" principle into the third party processing "who pollutes, who is responsible for" model to restrain the residents, tourists and business behavior with the law. Building an important social and cultural environment in the core area, we should favor and affirm those who protect the natural environment while criticize and punish those who harm natural environment. We can use a variety of cultural communication means (television, newspapers, networks) to promote terrestrial protection and cultivate the local residents with ecological way of thinking and make loving nature and protecting nature a social responsibility and way of life.

We should guide the medium and long term planning of Yuanyang local economic development by ecological thinking. In the development of long-term planning, Yuanyang County government should pay attention to promoting strategic environmental assessment, especially the planning assessment, that is, the territorial space should be in accordance with the requirements of the main functional areas and form economic, population, environment, resource coordination pattern. Making plans based on the EIA results and the major projects in core area should be established according to the EIA results. The theme of ecological civilization should be highlighted in long-term planning and the thinking of economic and social development and environmental protection are both important, synchronous, win-win should be implemented.

Guiding the ecological consumption development with ecological thinking. People in Hani terraced areas formed a self-sufficient lifestyle in early times, but foreigners' lifestyle gradually affected and changed the original way of Hani people. We should oppose excessive consumption, extravagant consumption, vulgar consumption, non-green consumption (green is not equivalent to natural, green consumption is not consumption of green) and other forms of improper consumption. By the integration of various forces we can promote education on changing the concept of consumption and form green consumption habits and cultivate green consumer culture.

\section{B. Conducting Ecological and Economic Development Projects}

It aims at solving the problem of income, which is an important condition to ensure that young workers can continue and inherit Hani rice terraces civilization. 


\section{1) Setting up the idea of green GDP development}

The eco-economic development approach has a supportive effect on promoting the development of the world heritage Hani terraces. We agree that the green GDP of the heritage core area must follow the 6R principle (reduction, reuse, reconsideration, reconsideration, re-repair, reintegration), making it basic principle for the development of Hani terraced agriculture, economy, culture and tourism [6]. At the same time, we hope that this concept can guide the development of medium and long-term planning of Yuanyang local economy and the ecological consumption patterns.

2) To build the superior agricultural industry chain in Red River Hani terraced area reasonably

The agriculture in terraced fields is dominated by traditional agriculture. Due to the low productivity, the income of farmers is limited, which can only meet the basic living needs of the villagers. Therefore, the government must adapt to local conditions to create regional advantages of agricultural industry chain to drive farmers to be rich. On the one hand, the government should improve rice production or new varieties by promoting agricultural science and technology. On the other hand, according to local conditions, the government should promote community support for agricultural projects [7], promote agricultural development model [8] (organic exquisite agricultural development model, eco-integrated agricultural development model, leisure and tourism agriculture development model), cultivate and protect Hani terraced wellknown brands, improve the ecological compensation policy of paddy fields [9] [10]. We should further improve the ecological industry chain between the planting industry, aquaculture and processing industry, reduce the three disturbances on the ecological environment scale as far as possible to establish the circular agricultural production system centered by water conservation and anti-degradation, form ecological agriculture with Hani characteristics.

3) Digging the potential and promoting agricultural ecotourism projects extensively and in depth

With the improvement of the visibility in the Honghe Hani terraces, visitors will be more and more. How to attract tourists throughout the year will become an important issue for resources developers and planners of the Honghe Hani terraced tourism. For example, the combination of sightseeing and experiential tourism makes visitors can temporarily stay away from the hustle and bustle of urban life, experience the fun of rural life, breathe fresh air, eliminate fatigue and relax in physical and mental by displaying and using the traditional farm tools, participating in the whole process of cultivation and tasting Hani organic farm meal without affecting the natural and cultural landscape of the terraced fields. At the places far away from core area, we can establish holiday resorts and farms represented by the rural resorts to provide social places for visitors, where emphasize the beautiful environment, supporting facilities, design of participation in the activities [11]. In the development process, we should fully reflect the enthusiasm, initiative and consciousness of residents in Hani village in protecting and developing terrace, pay attention to the participation of villagers in the development of tourism, concentrate on the scientific and rational layout of current and future types of accommodation facilities, village construction, folk song and dance performances, festival activities, the production of national handicrafts and other reception facilities. At the same time, we should give priority to the training and appointment of local village residents, make local villagers benefit in the development, able to share the results, then integrate in the sustainable development process of the terraced core scenic areas, and promote the development of terrestrial buffer zones, really inspire enthusiasm and vitality of the villagers to protect and develop their hometown to finally maintain the lifestyle and cultural traditions of local villagers.

\section{Implementing Habitat Projects}

Focusing on the disorderly construction and the construction deviate from the national style within the heritage protected area and advocating green low-carbon life style of the village residents.

\section{1) Speeding up making scientific and unified development} plan

The local government is lagging behind the local residents in the world cultural heritage reserve in terms of the future development plan. Among them, the planning of tourist attractions is also included. Thus, in the village protection and beautiful home construction process, we should pay attention to reflecting the original cultural landscape. Strictly plan and control the old village and reasonably arrange the new village.

2) Strengthening the management of the housing construction of the villagers

The value of traditional villages is hidden in the seemingly dull design, profoundly reflecting the characteristics of symbiosis with nature. With the development of the village style improvement and facilities improvement for the purpose of tourism, we should pay attention to the protection of the symbiotic relationship between traditional villages and terraces. In particular, some public buildings, such as schools, village office space, should take into full consideration. Their shape, color should conform to the surrounding environment as much as possible, to be new but not special as far as possible, and the architectural style should reflect the local national characteristics rather than simply copy that in the cities. The wall should not decorate with tiles and the road should be built with flagstone. Meanwhile, we should also take the improvement of the living conditions of the villagers into account, and other traditional architectural elements such as the use of fire ponds and the house pillars should be reorganized and developed with the improvement of economy, culture and living conditions.

3) Advocating an environmental-friendly, low-carbon and economic life style

We should focus on land-saving, energy-saving and materials-saving and strive to improve energy utilization efficiency [12] [13]. Promote the use of biogas from fermentation of rice straw. Wind energy, solar energy and other new environmental protection technology should be appropriately popularized in the core area. But in general, we should coordinate according to the whole landscape and the using function. If we distribute them freely, their unexpected presence in the village will affect the authenticity of the terraced landscape. We should also consider later maintenance, 
otherwise they will be out of use after construction, which brings a lot of inconvenience and waste to the rural environment and personal families.

\section{Implementing Democratic Management Innovation Project}

Residents of Honghe Hani terraced village have established the party's grassroots organizations and self-government organizations. We should fully display the positive role of ancestral concept formed in a long time in dealing with affairs at the grass-roots level to maintain the stable but relatively fragile ecological system in Hani. Sustainable development is an important content of democratic management innovation.

1) Paying attention to cultivating subjective consciousness offarmers

Guiding the villagers to change from "guiding by government" to "farmers self-management", encouraging farmers to actively participate in the protection of the world cultural heritage and management affairs as well as regulations of building beautiful home.

\section{2) Conducting civilized villages and towns construction} activities in depth

Strengthening the construction of public cultural facilities, such as rural cultural activities facilities. Using the cultural activities places of village level to popularize and train farmers to improve their cultural quality. Deepening the mass spiritual civilization creating activities, actively carrying out civilized selection activities such as civilized village group, civilized family and civilized households, aiming at protect and inherit the world cultural heritage and playing a typical demonstration role; carrying out transform social traditions activities in depth combined with rural custom comment to promote farmers to change their lifestyles and form a new rural civilization fashion.

\section{E. Implementing the Residents' Social Security Project}

It aims at eliminating local residents' worries to ensure that people are willing to live in the terrace. This requires the relevant government departments take some measures. One is to expand social security coverage. Social pension insurance and new rural cooperative medical insurance should be done and involved in the system; improve the rescue mechanism to effectively improve the living standards of the masses; establish rural hardship assistance system, poor student assistance system and family planning family support system. The other is to establish effective contradictory mediation mechanism to prevent and resolve rural conflicts and disputes.

\section{F. Implementing Ecological Legal Protection Project}

We should use the ecological way of thinking to improve the laws and regulations related to Hani terrestrial ecosystems, further improve and implement the established relevant terrestrial protection laws and regulations and modify the current situations at the same time. We should establish the corresponding laws on waste disposal, including relevant laws and regulations related to life waste, production waste and packaging and ensure that the laws are implemented in the protection of the terraces. Implementing the "polluter burden" principle, we should change the past "who pollutes, who control" principle into the third party processing "who pollutes, who is responsible for" model to restrain the residents, tourists and business behavior with the law. Building an important social and cultural environment in the core area, we should favor and affirm those who protect the natural environment while criticize and punish those who harm natural environment and give a certain amount of fine at same time. We can use a variety of cultural communication means (television, newspapers, networks) to promote terrestrial protection and cultivate the local residents with ecological way of thinking and make loving nature and protecting nature a social responsibility and way of life.

\section{CONCLUSION}

All in all, protecting terrace and building a beautiful home is not simply an integration of village appearance, but a comprehensive and diversified reflection on the development of rural economy and social progress. It embodies the value of protecting world heritage and ecology, a society including rural politics, economy, science and technology, education, transportation, national life and public security.

\section{REFERENCES}

[1] Jue Yuanmei. Ecological researches on the Natural and cultural landscape of Hani terrace. [M]. Beijing: China Environmental Science Press, Jun, 2009.P 88 to 125.

[2] Wang Qinghua. On terrace culture-Ecological agriculture of Hani ethics [M].Kunming: Yunnan People's Publishing House, Jul, 2010.

[3] Lu Peng. Ecological problems on Red River Hani terrace and solving solutions[J]. Archaeological Studies. Apr, 2012. P 195 to 198.

[4] Liu Xiaoxing. How to extend Hani terraced culture[N]. China Environment News, Jan, 8th 2014 (04)

[5] Zhao Jianjun. How to achieve the beautiful China dream[M]. Beijing: Intellectual Property Publishing House, Jun, 2013.

[6] Liu Xiangrong. Researches on Chinese ecological development strategy[M]. Beijing: People's Publishing House, Jan, 2013.

[7] Elizabeth Henderson, etc. Sharing the harvest - a citizen's guide to Community Supported Agriculture [M]. Beijing: China Renmin University Press, Feb, 2012

[8] Li Huibin, etc. Ecological civilization \& Marxism[M]. Beijing: Central Compilation \& Translation Press, Oct, 2008. P 107 to 122.

[9] Liu Moucheng How to establish the ecological compensation standards for rice fields in traditional areas - take a case study by Hani terrace in Yunnan Province [J]. Chinese Journal of Eco-Agriculture. 2012. 20(6): $703-709$.

[10] Liu Moucheng, Xiong Ying, etc. Study on the Ecological Compensation Standard of Hani Terrace Based on Ecological Function Improvement. [J]. Acta Oecologica .2017.37(7):1-8.

[11] Chen Xiaobo. Following by the success of Hani terrace[N]. Yunnan Daily, Jun, 24th 2013(02)

[12] Yang Shenxuan. Carrying out the Harmonious Ecological Values of Hani People Based on Terraced Fields [J]. Agricultural Archaeology. Jan,2013. P 282 to 285

[13] Zhao Yun, etc. A Study on the Scientific Characteristics of Habitat Environment in Hani Terraced Fields from the Perspective of World Heritage [J]. Urban Planning International. 2013.28(01):69 73.

[14] Felden benard, etc. Management guidelines for world cultural heritage sites [M]. Shanghai: Tongji University Press, Apr, 2008. 